\title{
A MAGYAR FELSŐOKTATÁS FEJLŐDÉSE A RENDSZERVÁLTÁS UTÁN
}

\section{DEVELOPMENT OF HUNGARIAN HIGHER EDUCATION AFTER THE CHANGE OF REGIME}

\author{
Polónyi István ${ }^{1}$, Kozma Tamás ${ }^{2}$ \\ 1CSc, egyetemi tanár, Debreceni Egyetem Bölcsészettudományi Kar Nevelés- és Múvelődéstudomány Intézet (levelező szerző) \\ istvan.polonyi@arts.unideb.hu \\ ${ }^{2}$ DSC, professor emeritus, Debreceni Egyetem Bölcsészettudományi Kar Nevelés- és Múvelődéstudomány Intézet \\ kozmat@ella.hu
}

\section{ÖSSZEFOGLALÁS}

Ebben a tanulmányban a magyar felsőoktatás rendszerváltozás utáni fejlődésének sajátosságait elemezzük. A felsőoktatás Magyarországon - és sok tekintetben valamennyi posztszocialista országban - sajátos utat tett meg. A fejlett világ felsőoktatási fejlődésének jellegzetességei megkésetten és átalakulva, nem ritkán torz módon jelennek meg.

\section{ABSTRACT}

In this study, we analyse the peculiarities of the development of the Hungarian higher education system after the change of regime. The higher education in Hungary - and in many respects in all post-socialist countries - had a special path. The characteristics of higher education development in the developed world appear to be delayed and transformed, often distorted.

Kulcsszavak: az egyetem egyesületi modellje, az egyetem üzleti modellje, az egyetem bürokratikus modellje, az egyetemek történelmi fejlődési útja, az egyetemek magyar fejlődési útja

Keywords: the association model of the university, the business model of the university, the bureaucratic model of the university, the historical development path of the universities, the Hungarian development path of the universities

\section{AZ EGYETEMEK FEJLŐDÉSI ÚTJA}

Az egyetemek szervezetének három fejlődési típusa különböztethető meg az egyesületi (vagy önkormányzati), a hivatali (vagy bürokratikus) és a vállalati (vagy vállalkozási) (Kozma, 2004; Szabó, 2014). Az egyesületi forma a teljes gaz- 
dasági és akadémiai autonómiát jelenti, a vállalati a gazdasági autonómiát - ami az akadémiai autonómiát erősen visszaszorítja -, a hivatali formában pedig mind az akadémiai, mind a gazdasági autonómia erősen korlátozott.

Az egyes országok, országcsoportok egyetemfejlődése jelentős különbségeket mutathat, de a történelmi fejlödési ív az egyesületi modelltől az egyesületi-bürokratikus vegyes modellen át vezet a vállalkozási modell felé (1. ábra, folyamatos vonal). A fejlődési lehetőségek sokszínüek, mint ahogy a végeredmény (pontosabban inkább a mai fejlettségi állapot), amely a fejlett világ nagy részében a nagyvállalati egyetem, amely ennek az egyesületi-vállalati modellnek valamilyen formája (Hrubos, 2000).

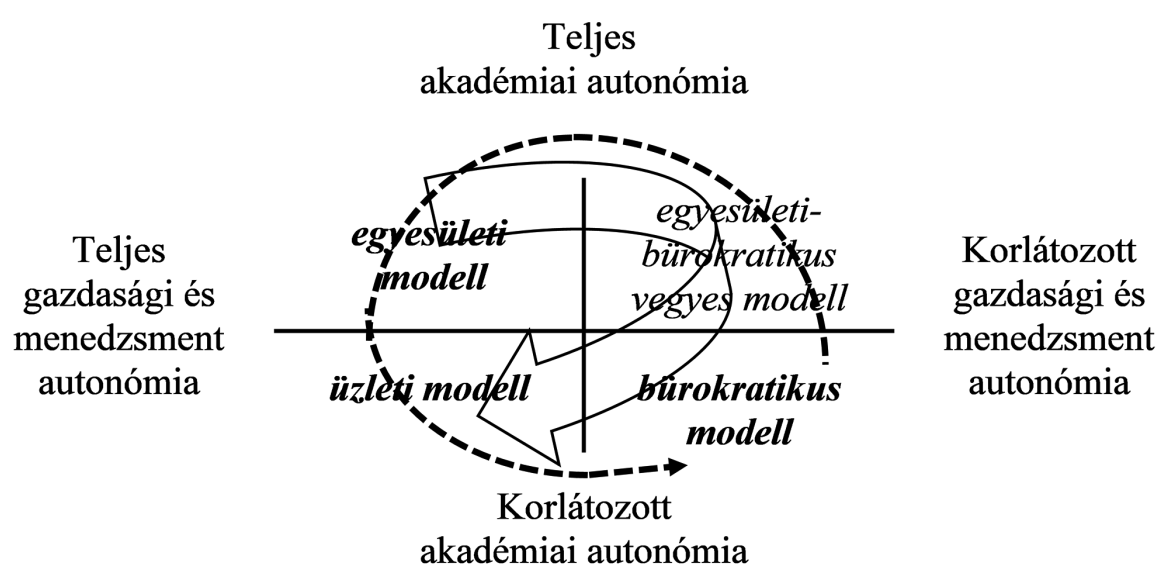

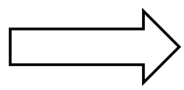

Az egyetemek történelmi fejlődési útja
Az egyetemek magyar fejlődési útja

1. ábra. Az egyetemek fejlődési útja (saját koncepció)

A magyar egyetemfejlődési út a 20. század közepétől napjainkig más. Az államszocialista időszak hivatali felsőoktatását követően a rendszerváltozás nyomán mintegy rázuhant az egyetemekre az egyesületi modell, a teljes gazdasági és akadémiai autonómia. Ezt követően az egymást követő baloldali és konzervatív kormányok bár egymással ellentétes felsőoktatás-politikát követtek, abban mégis közös volt törekvésük, hogy az egyetemi egyesületi modellt a vállalati modell felé igyekeztek elmozdítani. 2010 után azonban a hatalomra került konzervatív koalíció hirtelen irányváltással a hivatali modell irányába tolta el az egyetemek szerveződését, egy alapvetően bürokratikus modellt kialakítva (1. ábra, szaggatott vonal). 


\section{A „MAGYAR ÚT” JOGI KÖRNYEZETE}

A magyar út megértéséhez elöször röviden megvizsgáljuk a felsőoktatás alkotmányos környezetét, majd a felsőoktatásra vonatkozó törvények legfőbb jellemzőit (lásd részletesebben Polónyi, 2015).

A magyar alkotmány, amely lényegében a rendszerváltás előtti alaptörvény 1989-es módosítása nyomán alakult ki, tartalmazta, hogy „,a Magyar Köztársaság tiszteletben tartja és támogatja a tudományos és múvészeti élet szabadságát, a tanszabadságot és a tanítás szabadságát”. A 2011-ben elfogadott Alaptörvény viszont így ír: „... felsőoktatási intézmények a kutatás és a tanítás tartalmát, módszereit illetően önállóak, szervezeti rendjüket törvény szabályozza. Az állami felsőoktatási intézmények gazdálkodási rendjét törvény keretei között a Kormány határozza meg, gazdálkodásukat a Kormány felügyeli”. Az új megközelítés nyilvánvalóan leszűkíti az egyetemi autonómiát, kiemelve abból a szervezetalakítást és a gazdálkodást.

A következőkben a magyar felsőoktatási törvények jellemzőit tekintjük át röviden (lásd részletesebben Polónyi, 2017).

Az államszocializmus utolsó oktatási törvénye 1985-ben született, ebben a felsőoktatás célja a gazdaság igényei szerinti szocialista szakemberképzés volt. A rendszerváltás idején kormányzó utolsó kommunista kormány a 1990. évi törvényében már elhagyta a szocialista jelzőt, csak felsőfokú szakemberképzésről írt. A rendszerváltás utáni első polgári kormány törvénye a felsőfokú szakemberképzés mellett az értelmiségi létre nevelésről is ír, és az 1996-os baloldali koalíciós kormány törvénymódosítása is hasonló szellemü. A 2005. évi baloldali kormány törvényében az értelmiségi képzési feladatok mellett megjelenik a munkaerőpiac igényeinek megfelelő képzés. Az újabb konzervatív kormány 2011. évi felsőoktatási törvényében az értelmiségi szó egyszer sem szerepelt, mint ahogy a műveltség szó sem, viszont az előkészítő anyagokban a munkaerőpiacnak meg nem felelő felsőoktatás igen erőteljes hangsúlyt kapott.

A felsőoktatás céljainak átalakulásával párhuzamosan az intézményi autonómia is módosul. Az 1993-as törvény egy klasszikus humboldti egyetemet definiál lényegében teljes akadémiai és jelentős gazdasági, szervezeti autonómiával. 1996-ban a gazdasági autonómiát jelentősen megkurtítják azzal, hogy a felsőoktatási intézményt központi költségvetési szervnek nyilvánítják, s gazdálkodási, különösen vagyongazdálkodási szabadságát radikálisan korlátozzák, központi engedélyhez kötik. Az ezredfordulón a konzervatív kormány az akadémiai autonómián szűkít, amikor az egyetemi tanári kinevezést akkreditációs bizottsági engedélyhez köti, a felsőoktatási felvételt pedig központi rendszerré alakítja, megszüntetve az intézmények önálló felvételi tevékenységét. A 2005. évi baloldali kormány a gazdasági autonómiát jelentősen kibővíti, s az intézményeket a gazdálkodói egyetem vezetési, szervezeti és gazdálkodási szabályai felé mozdít- 
ja el, de az akadémiai autonómia korábban kialakult rendszerén nem változtat. A 2011-es konzervatív kormány ismét radikálisan beszűkíti a gazdasági autonómiát, és az akadémiai autonómián is szorít azzal, hogy a szakalapítást minisztériumi engedélyhez köti. A második ciklusát töltő konzervatív kormány pedig 2015-ben bevezeti a kancellári rendszert - ezzel radikálisan csökkentve a rektor döntési jogkörét, a szenátusét pedig lényegében csupán szimbolikussá téve.

A magyar fejlődési utat tehát úgy is interpretálhatjuk, hogy a felsőoktatás-politika a rendszerváltást követő huszonöt évben mintegy végigrohan azon a fejlődési pályán, amelyet a fejlett országok felsőoktatása több mint fél évszázad alatt járt be, $\mathrm{s}$ túl is szalad azon (mint az egyik nem túl régen távozott - a felsőoktatást is felügyelö - miniszter mondta a központosítással kapcsolatban: „túltolták a biciklit”).

Az állam törekvésének mind Nyugaton, mind Keleten az az indoka, hogy a tömegessé vált felsőoktatás egyre fontosabbá válik a politikai szféra számára: a kormányzatnak mind nagyobb aggodalmat jelent az egyre növekvő felsőoktatással kapcsolatos kiadás, ezért minden eddiginél jobban érdekeltté válik abban, hogy mind a hallgatók, mind pedig a kutatások szempontjából befolyásolja a felsőoktatási intézmények termékkínálatát (Bleiklie-Kogan, 2007).

\section{A SZERVEZETI ÉS VEZETÉSI JELLEMZŐK FORMÁLÓDÁSA}

a) A hivatali modelltól a hivatali modellig

Mint arról korábban volt szó, az egyetemek - és a magyar posztszocialista egyetemek - szervezetének három típusa különböztethető meg (Kozma, 2004).

Az egyetemet mint bürokratikus szervezetet Magyarországon az államszocialista korszak alakította ki (alakította újjá); föképp azzal, hogy a kormányzat tervezési bürokráciája szabta meg az egyetemek pályáját és mozgáslehetőségeit. Az egyetem mint önkormányzat eredetileg leginkább azokhoz a szervezetekhez hasonlított, amelyek - beékelődve a kapitalizálódó társadalmakba (még inkább megelőzve azokat) - önszerveződő társadalmi egységként keletkeztek. A magyar fejlődésben ez a rendszerváltozást követően a párt és pártállam összeomlása nyomán, a felső és belső kontroll megszünésével alakul ki.

Mára azonban a fejlett országokban az egyetemek kezdenek hasonlítani a vállalkozásokhoz. (Bár, mint Hrubos Ildikó figyelmeztet: az, amit az egyetemek folytatnak, legföljebb gazdálkodás a rendelkezésükre bocsátott, túlnyomórészt állami forrásokkal, nem pedig vállalkozás [Hrubos, 2004].) Az egyetemek nem váltak kis- vagy középvállalkozásokká, ahogy a privatizáció hívei egykor szorgalmazták (Neave, 1988).

A nagy egyetemi összevonások időszakában (Európa-szerte az 1980-90-es években; Magyarországon az ezredfordulón, lásd erről: Híves et al., 2019) még 
senki sem gondolt azokra a szervezeti fejleményekre, amelyek fokozatosan kibontakoztak. A számos kényszerü vagy menekülésszerú csatlakozás eredményeképpen néhány magyarországi egyetemnek szerteágazó, trösztszerủ szervezete lett (Teperics, 2005; Rechnitzer-Smahó, 2011). A müködést alcentrumok kialakulása tette lehetővé, amelyekben összeszövődtek az egyetem-tröszt különféle tevékenységei és a gazdaság velük együttműködő egységei.

A nagyvállalati szervezet kibontakozása mély nyomokat hagy az egyetem belső világában. Az egyetemet eredetileg alkotó csoportok helyzete megváltozik.

A hallgatók és a mögöttük álló társadalmi csoportok gazdasági és politikai elvárásai meghatározó szerepet játszanak a nagyvállalattá fejlődésben (úgy is mint hajtóerő, de úgy is mint akadályozó tényező). Ugyancsak sok példát hoztak föl és következtetést vontak le a vonatkozó publikációk az egyetemi adminisztrátorok fölértékelődéséből (Reed, 1999; Deem et al., 2007). A menedzserizmus, a nagyvállalattá váló egyetemek ideológiája, jórészt hozzájuk füződik.

A posztszocialista „egyetemvállalat” előtt korántsem szabad a piac. Ezt a piacot - mint bármely állami nagyvállalatét - maga az állam osztja föl. Ahelyett, hogy versenybe bonyolódnának a szolgáltatásaikkal, kialakították és akár állami segítséggel biztosítják is maguknak a piacot, amelyen „szolgáltatási monopóliumuk" van (Híves et al., 2000; Kozma et al., 2000).

Az állami nagyvállalatoknak - legalábbis Magyarországon - nincs igazi versenytársuk, már csak szolgáltatási monopóliumuk miatt sem. Legföljebb a nemzetközi versenyben méretnek meg, vagy akkor, ha idegen szolgáltató kap lehetőséget a behatolásra a hazai piacon. Az egyetemek mint állami nagyvállalatok azonban megúszták az efféle behatolást. És úgy látszik, a Bologna-folyamat keretében megszilárduló nemzeti felsőoktatási rendszerek az európai felsőoktatási térséget is garantálják - mint egyfajta szellemi vámhatárt.

Ahogy megnyíltak Magyarország korábban államilag lehatárolt piacai - hogy beengedjék, sőt hívják a nemzetközi vállalatóriásokat -, úgy indultak meg egy korábbinál engedékenyebb kormányzati légkörben, nemegyszer önkormányzati támogatással, a már említett fél-felsőoktatási vállalkozások. Bár ezek a képzések ún. piaci alapon szerveződtek, ez a „piaci alap” azonban végső soron ugyancsak állami pénzt jelentett. A települési (városi) önkormányzatok föiskolát alapító törekvései szintén állami forrásokra nyúltak vissza.

A gazdasági szabadság eszméje (neoliberalizmus) különösen azokat a területeket uralta, amelyek korábban tervgazdasági felügyelet alatt állottak. Bürokratikus tervezés helyett piaci környezetet és hatásokat vártak, amelyek eredményeképpen a (népgazdasági) tervezés vállalati tervezéssé és stratégiaformálássá volt átalakulóban. Ebben a légkörben az egyetemek irányítása is megváltozott. Az 1990-es évek végére már eléggé egyértelmü volt a ,gazdálkodó egyetem” modelljének kirajzolódása (Hrubos, 2004). 
A 2000-es évek első évtizedének kezdetére azonban a magyar politika sajátos konzervatív fordulata elsöpörte a gazdálkodó egyetem modelljét.

Szabó Tibor 2014-ben áttekintette a felsőoktatási törvényeket a vezetés szempontjából. Megállapította, hogy az államszocialista időszak utolsó oktatási törvényében (1985. évi oktatási törvény) még egyszerre szerepel a titkár (főtitkár) és a hivatalnok (gazdasági vezető), jelezve a felsőoktatási intézmény félig egyesület, félig hivatal státusát. Az állami befolyás erős, a rektoron, rektorhelyetteseken és az említett két vezetőn kívül a dékánok is miniszteri jóváhagyással nevezhetők ki. Az 1993-as felsőoktatási törvény a hivataliból az egyesületi modell irányába tolja vissza a menedzsmentszerkezetet. A vezetők, a gazdasági vezető kivételével választottak, kiválasztásuk belső szabályok szerinti. A 2005-ös törvény már számos ponton szakít az egyesületi modellel, elsősorban profeszszionalizálási célból. Az akkorra már tömegoktatássá vált felsőoktatás tapasztalatait értékelve arra a vélelemre épít, hogy az egyesületi modell színvonalas tömegtermelésre alkalmatlan.

2010-től azután fordulat következett be a fenntartó és az intézmények viszonyában, mert az üzleties menedzsmenteszközök egyértelmúen kudarcot vallottak. A felsőoktatás területén - de sok más területen is - az alkalmazott forprofit technikákat száműzték. Szabó $(2014,23$.$) megfogalmazásában: „Az irányító$ szervek úgy vélik, hogy az egyértelmü alá- és fölérendeltség helyett a mellérendelt viszonyok gyengék. Nekik nincs elég szellemi erejük (az üzleties megközelítések elméletében és gyakorlatában járatlanok) és motivációjuk (a fenntartó is nonprofit, azaz gyengén motivált) a megfelelő teljesítménymenedzsment-rendszerek működtetéséhez. Az intézmények ugyanakkor már elég gyakorlottak ahhoz, hogy a pongyolán megfogalmazott szabályok alól kibújhassanak, bármilyen felelősségre vonást elkerüljenek. Ezért a bizalomra, közös értékekben hívő, hosszú távú elképzelésekre alapozott kapcsolat kevésbé hatékony, mint a szankciókra, egyoldalú, nem magyarázott elhatározásokra, állandó fenyegetettségre épülő »hagyományos modell«.” Szabó úgy véli, hogy „lényegében a (piaci) szocializmus-menedzsment elveihez és technikáihoz nyúl vissza a 2015-ös kancellári modell, amelynek feltételezése, hogy a felsőoktatás bonyolult viszonyrendszere egyszerü eszközökkel menedzselhető. Pusztán egy kiválasztott és az intézményi érdekcsoportoktól független vezető megoldja a hatékonysági problémákat. A (magyar) kancellári modellben a kancellár rektori hatásköröket vesz át, illetve korlátoz, a feltételezetten helytelenül müködő intézményeket »igazítja el«, kizárva az »akadémiai vezetőket« az érdemi döntésekből, s a rektori hatásköröket megkurtítva. A modell indoklásában nagy hangsúlyt kap a tulajdonosi szerep erősítése, az intézményi belső szolgáltatások jó színvonalú működtetésére azonban sem érdekeltségi rendszert, sem kontrollmechanizmusokat nem tartanak szükségesnek." (Szabó, 2014, 25.) 


\section{b) Akkreditáció}

Az akkreditáció ismeretlen fogalom (ismeretlen politika) volt még az 1980-as években is Európa keleti felének országaiban. Az államszocializmus bürokratikus egyetemén ugyanis nem volt minőségbiztosítás, pontosabban a minőségbiztosítás a pártellenőrzés volt. Az akkreditációval csak a rendszerváltozás hajnalán kezdtek ismerkedni az oktatásirányítók és a felsőoktatási intézmények.

Egy futó összehasonlításból - amely az angliai, a francia- és a németországi gyakorlatot vetette össze (Kozma-Rébay, 2006, 16-48.) - annyi kiderült, hogy a felsőoktatási akkreditációnak eltérő modelljei vannak/lehetségesek. Annak a vizsgálódásnak az időpontjában - az 1990-es évek végén - még úgy tünt, hogy nyitva áll az út egy bürokratikusabb (francia) vagy egy piacosabb (angol) gyakorlat előtt. Amikor azonban a kutatók a kelet-közép-európai akkreditációs politikákat összehasonlították, merőben más kép bontakozott ki. Nyíltabban vagy csak alig burkoltan az állami irányítás tért vissza a felsőoktatásba. Az akkreditáció nem a piac közbeékelésének látszott a kelet-közép-európai államok felsőoktatási politikájában, hanem az állam kinyújtott karjának, amellyel igyekszik újra viszszaszerezni hatalmát a felsőoktatás fölött, amelyet a rendszerváltozások közben elvesztett.

A magyar akkreditációs testület nagyjából hasonló fejlődésen ment át, mint a felsőoktatási autonómia. Eleinte tagjait a felsőoktatási intézmények és a kutatóintézetek delegálták, majd később a közoktatás és a különböző felhasználói szervezetek is küldtek tagot, és az elnökét maga választotta. 2010-től viszont jelentős változás következett be, egy ideig tagjainak többségét - később az ENQA (European Association for Quality Assurance in Higher Educatio, Felsőoktatási Minőségbiztosítási Ügynökségek Európai Szövetsége) tiltakozása után, a tagoknak csak egy híján a felét - a miniszter delegálja és elnökét is ő nevezi ki.

\section{c) A posztszocialista menedzserizmus}

Az oktatásügyi menedzserizmus néhány meggyőződése (hiedelme) a hazai posztszocialista felsőoktatás-irányításban is közismertté, sőt elfogadottá vált.

- Az oktatásügy mint szolgáltatóipar. A vállalatirányítás szemlélete és módszerei úgy válnak alkalmazhatóvá, hogy azokat gazdasági tevékenységekkel azonosítják, például az oktatásügyet a szolgáltatóiparral. Ebben a szemléletben a szolgáltató az iskola, az egyetem (egyes megfogalmazás szerint „oktatási szolgáltatást nyújtó intézmény”); a szolgáltatást igénybe vevők a tanulók és/vagy a mögöttük álló, általuk megjelenített társadalmi csoportok (például a szülők). A pedagógus a szolgáltatásban alkalmazott munkaerő („oktatásügyi szakalkalmazott”). Maga a szolgáltatás pedig az, hogy az iskola, az egyetem feleljen meg a munkaerőpiac követelményeinek, adjon 
„teljesítményképes” diplomát. Így a „munkaerőpiac” elvárásai diktálnak az egyetemnek, nem pedig az a sokkal szélesebb társadalmi közeg, amely az egyetemet körülveszi (Deem, 2001). Ugyanakkor a 2010-es konzervatív oktatáspolitikai fordulat után már nem szolgáltatásról, hanem közszolgálatról van szó.

- Intézményi minőségbiztositás. Az oktatásügyi szolgáltatásnak ugyanúgy egyenletes minőségünek kell maradnia, mint minden más szolgáltatásnak. A vállalati minőségbiztosítási rendszerek nem alkalmazhatók a tudományos világra, mert más a filozófiájuk. Mégis alkalmazzák őket, nemcsak mert nemzetközi elöírások diktálják a hazai felsőoktatásnak, hanem mert valódi, a felsőoktatási intézményre szabott minőségbiztosítást még nem sikerült kidolgozni. Az intézményi minőségbiztosítások letudandó rutinokká válnak, amelyet az akadémiai világ peremén állók végeznek, $\mathrm{s}$ ez az „egyetemvállalat" irányítói számára kötelező penzum. A minőségbiztosítás elsősorban az oktatók (a szakalkalmazottak) folyamatos, adminisztratív jellegü ellenőrzése. Ez is sajátos fejlődésen megy át a magyar felsőoktatás alakulásának útján. Az 1993. évi törvény még csak az akkreditáció kapcsán említi a minőséget, a 2005. évi törvény már a menedzserializmus jegyében intézményi minőségbiztosítási rendszereket és kormányzati minőségbiztosítást hoz létre, s az akkreditációt csak időszakos, és főleg belépési minőségértékelésnek fogja fel. A 2010-es törvény viszont ismét csak az akkreditáció minőségellenőrző szerepét értelmezi. A minőségbiztosítás tehát egyedül az államosított akkreditáció marad, mint az állam egyik ellenőrző eszköze a posztszocialista bürokratikus egyetemi modellben.

- Belsö irányitási rendszerek. Irányitás ,,bizonyitékok” alapján (evidence based). Mint minden nagyvállalatnak, az „egyetemvállalatoknak” is megvan a maguk ún. belső irányítási rendszere. Az „,egyetemvállalatok” Magyarországon ezt a közelmúltban fejlesztették ki (ilyen az, ,adatalapú vezetői információs rendszer”, a „diplomás pályakövetési rendszer”, a már hosszabb ideje müködők közül a „hallgatói, tanulmányi nyilvántartási rendszerek”). Mindegyikben az a közös, hogy miközben intézményi belső rendszereknek indultak, mára a kormányzati ellenőrzés és irányítás eszközeivé is váltak.

- Rangsorok. Az intézményi rangsorokat eredetileg a hallgatók orientálására szánták, mára azonban nemzetek fölötti versenylistává alakultak át. Az oktatói tevékenységekből kiemelkednek a kutatói teljesítmények, ezek mérése szakmává vált. Az intézményi, nemzeti és nemzetközi adatbázisok a tudományos publikációkról, tájékoztatásból fokozatosan átalakultak az oktatók és kutatók teljesítményének ellenőrzésévé, és egy „evidence based” felsőok- 
tatási politika egyik eszközévé váltak. A magyar felsőoktatás finanszírozásában mindig szerepet játszottak kisebb nagyobb mértékben a minisztériumi értékelések nyomán kézzel osztott források. A 2010-es oktatáspolitikai váltás nyomán az intézményi „kiválóság” külön állami pénzelőirányzat lett, amelynek elosztási kritériumai azonban nem átláthatóak.

Az „új értékelő állam” nyelvét az egyetemi vezetők és adminisztrátorok is igyekeznek megérteni. Kénytelenek is, ha egyszer kapcsolatban állnak fönntartójukkal, az állammal.

Mint Szabó Tibor (2014) megállapítja, a magyar felsőoktatás menedzsereit általában amatőrizmus jellemzi. Egyetlenegy magasabb vezető vagy minisztériumi, fenntartói vezető esetében sem követelmény, hogy a gazdálkodás- és szervezéstudomány területén valamilyen végzettséggel rendelkezzék, vagy jártassága legyen a felsőoktatási marketing, pénzügyek, minőségbiztosítás, emberi erőforrás-gazdálkodás stb. területén. A vezetői pozíciók általában oktatói munkakörökhöz kapcsoltak, az ágazati menedzserek is intézményhez, az intézményiek karhoz, tanszékhez kötődnek. Ebből is adódik, hogy a „piacosítási” kísérletek kudarcba fulladtak, s erősödik a bürokratikus koordináció, centralizáció. Részint a gazdasági-vállalkozási tevékenységre alkalmatlan az egyesületi felsőoktatási modell, részint pedig a fenntartó professzionalizációjának hiányai miatt, valamint a gyors megoldáskeresése okán a központi irányításnak nem felel meg a piaci koordináció.

Ha végigtekintünk a magyar felsőoktatást is magában foglaló szférát irányító minisztereken a rendszerváltást követően napjainkig, azt látjuk, hogy közülük „eredeti foglakozását” tekintve fele részük jött az akadémiai szférából, fele részük pedig politikus. Egyáltalán nem látszik valamilyen egyirányú tendencia a folyamatban. Nem látszik, hogy a miniszteri státusz inkább politikusi státusszá alakulna, ami a politika professzionalizálódását jelezné. Ugyanakkor a szűkebb felsőoktatási tárcaterület irányítását a rendszerváltás óta túlnyomó többségében vezető egyetemi oktató (egyetemi tanár, illetve egyetemi docens) látta el. E poszt betöltỏjének egyre inkább az irányított szférából kell kikerülnie, hiszen ő tart kapcsolatot a szférával. Az autonómia csökkenésével mind több feladat kerül a minisztériumhoz, amelyet olyan személynek kell kontrollálnia, aki érti a szféra müködését.

\section{ÖSSZEFOGLALÁS}

A felsőoktatás modelljeinek átalakulása világjelenség, de abban a formában, ahogy Kelet-Közép-Európában kibontakozott, másutt nem találjuk. Ennek oka - mint a gazdaság és a politika csaknem minden fejleményének oka az elmúlt harmad évszázadban - a rendszerváltozásban keresendő. 
A rendszerváltozás hozta létre azt a mintát - azt a gazdasági-szervezeti hátteret -, amely eleinte létrehozta az ,egyetemvállalatokat”, s a trösztösödés (és vele egy látens kartellezés) felé nyomta. Az „egyetemvállalati” szervezetben fokozatosan leértékelődik a korábbi legbefolyásosabb csoport, az oktatók. Viszont fölértékelődik az egykor lenézett és lekezelt egyetemi adminisztráció. A „felsőoktatási menedzserizmus" az ö tudományuk (Kozma, 2011).

A 2000-es évek első évtizede azonban gyökeres változást hozott. A felsőoktatási intézmények vélt vagy valós képzési és gazdálkodási problémái nyomán az oktatáspolitika véget vetett az egyetemvállalati kísérletnek, $\mathrm{s}$ helyébe radikális központosítás, a gazdasági és akadémiai autonómia szűkítése, azaz a bürokratikus modell visszaállítása lépett. A korábban a menedzserizmushoz kapcsolódó „új értékelő állam” helyére a régi, direktív, központosítva irányító állam lépett.

A magyar menedzserizmus sajátos vonása, hogy éppen azok alakították ki, akik a tervgazdaságban szocializálódtak, gyakran az államhatalom hivatalaiban. A posztszocialista bürokratikus egyetemi modellt is ők, illetve tanítványaik vezetik be. Ők az államszocializmus álpiaci viszonyai között felnőve vagy arra emlékezve nem hisznek a piaci koordinációban, csak a központi irányításban bíznak.

$* * *$

Jelen írás a szerzőknek a Management Learning felhívására írt, Development of Hungarian Higher Education after the Change of Regime címü tanulmányának rövidített és átszerkesztett változata.

IRODALOM

Bleiklie, I. - Kogan, M. (2007): Organization and Governance of Universities. Higher Education Policy, 20, 477-493. DOI: 10.1057/palgrave.hep.8300167, https:/www.researchgate.net/publication/43901722_Organization_and_Governance_of_Universities

Deem, R. (2001): Globalisation, New Managerialism, Academic Capitalism and Entrepreneurialism in Universities: Is the Local Dimension Still Important? Comparative Education Review, 37, 1, 720-731. DOI: 10.1080/03050060020020408, https://bit.ly/2SDifht

Deem R. et al. (2007): Knowledge, Higher Education and the New Managerialism. The Changing Management of UK Universities. Oxford: Oxford University Press, DOI: 10.1093/acprof:oso/9780199265909.001.0001, https://bit.ly/38Bedvy

Híves T. et al. (2019): From Fragmentation to Concentration and Beyond. In: Cremonini L. et al. (eds.): Mergers in Higher Education. New Delhi: Studera Press

Hrubos I. (2000): A felsőoktatás nagy modelljei és módosulásuk a huszadik század második felében. INFO Társadalomkutatás, 49.

Hrubos I. et al. (2004): Gazdálkodó egyetem. Budapest: Felsőoktatási Kutatóintézet-Új Mandátum Kiadó

Kozma T. (2004): Kié az egyetem? A felsőoktatás nevelésszociológiája. Budapest: Új Mandátum Kiadó, http://mek.oszk.hu/08900/08962/08962.pdf 
Kozma T. (2011): „Egyetemvállalat” és menedzserlializmus. Educatio, 19, 4, 461-471. http://www. hier.iif.hu/hu/letoltes.php?fid=tartalomsor/2101

Kozma T. et al. (2000): Regionális együttmüködések a harmadfokú képzésben. Budapest: Oktatáskutató Intézet

Kozma T. - Rébay M. (szerk.) (2006): Felsőoktatási akkreditáció Közép-Európában. Budapest: Új Mandátum Kiadó, https://mek.oszk.hu/08900/08925/08925.pdf

Neave, G. (1988): On the Cultivation of Quality, Efficiency and Enterprise: An Overview of Recent Trends in Higher Education in Western Europe 1986-88. European Journal of Education, 23, 1-2, 7-17. DOI: $10.2307 / 1502961$

Polónyi I. (2015): A hazai felsőoktatás-politika átalakulásai. Iskolakultúra, 25, 5-6, 3-14. DOI: 10.17543/ISKKULT.2015.5-6.3, http://real.mtak.hu/34801/

Polónyi I. (2017): Az oktatáspolitika müveltségképe. Neveléstudomány, 1, 5-14. DOI: 10.21549/NTNY.17.2017.1.1, http://nevelestudomany.elte.hu/downloads/2017/nevelestudomany_2017_1.pdf

Rechnitzer J. - Smahó M. (2011): University Cooperations along the Austrian-Hungarian Border: Experience of an Empirical Research. In: Semenčneko, D. - Matejić, V. (ed.): Technologija, Kultura, Razvoj. Belgrad: Akademska misao, 56-66. http://www.tehnologi-jaidrustvo.org/Prilozi/ZBORNIK\%20TKR17-10.2-2.pdf (Letöltve: 2011. 10. 13.)

Reed, C. M. (1999): 'New Managerialism' and the Management of UK Universities. http://www. leeds.ac.uk/educol/documents/189420.pdf (Letöltés: 2019. 12. 15.)

Szabó T. (2014): A tömegesedés és a hazai intézményi menedzsment. Educatio, 2. 270-281. http:// www.edu-online.eu/hu/letoltes.php?fid=tartalomsor $/ 2340$

Teperics K. (2005): Debrecen oktatási vonzáskörzete. In: Czimre K. (szerk.): Kisközségtől az eurorégióig. Debrecen: Didakt Kiadó, 58-71. 